\title{
Production performance and nutrient digestibility of lactating dairy cows fed low-forage diets with and without the addition of a live-yeast supplement
}

\author{
G. Ferreira, ${ }^{1 *}$ E. S. Richardson, ${ }^{1}$ C. L. Teets, ${ }^{1}$ and V. Akay ${ }^{2}$ \\ ${ }^{1}$ Department of Dairy Science, Virginia Tech, Blacksburg 24061 \\ ${ }^{2}$ Global Nutritech Biotechnology LLC, Richmond, VA 23219
}

\section{ABSTRACT}

We aimed to evaluate the use of a live-yeast product as a means to attenuate plausible nutritional disturbances when feeding relatively low-forage diets containing rapidly fermentable carbohydrates (i.e., wheat) to high-producing cows in early to mid lactation. Eight primiparous [mean $\pm \mathrm{SD} ; 569 \pm 35 \mathrm{~kg}$ of body weight (BW) and $80 \pm 29 \mathrm{~d}$ in milk (DIM) at the beginning of the experiment] and 16 multiparous $(665 \pm 67 \mathrm{~kg}$ of BW and $64 \pm 10$ DIM at the beginning of the experiment) Holstein cows were blocked by parity and DIM, and randomly assigned to 1 of 2 diets (control vs. yeast) for a 12-wk-long period according to randomized complete block design. The formulated diets contained 36.7\% corn silage, $8.3 \%$ alfalfa hay, and $55 \%$ concentrate. The yeast diet was formulated to provide approximately 5.4 $\times 10^{11} \mathrm{cfu} / \mathrm{d}$ of Saccharomyces cerevisiae (BeneSacc; Global Nutritech Biotechnology LLC, Richmond, VA). Total-tract nutrient digestibility was estimated using 240-h undigested neutral detergent fiber (NDF) as an internal marker. Dry matter intake, milk yield, and milk component concentrations and yields were analyzed using repeated measures. The statistical model for these variables included the effects of block, treatment, the block by treatment interaction, week, the treatment by week interaction, and the random residual error. The statistical model for analyzing BW gain, body condition score gain, and dry matter and nutrient digestibilities included the effects of block, treatment, and the random residual error. Supplementing live yeast to lactating dairy cows did not affect dry matter intake (26.0 $\mathrm{kg} / \mathrm{d}$ ), milk yield $(48.1 \mathrm{~kg} / \mathrm{d})$, milk fat concentration $(3.61 \%)$, milk fat yield $(1.72 \mathrm{~kg} / \mathrm{d})$, milk protein concentration $(2.96 \%)$, milk protein yield $(1.43 \mathrm{~kg} / \mathrm{d})$, milk lactose concentration $(4.84 \%)$, milk lactose yield $(2.35$ $\mathrm{kg} / \mathrm{d})$, milk urea nitrogen $(7.99 \mathrm{mg} / \mathrm{dL})$, body weight

Received January 29, 2019.

Accepted April 3, 2019.

*Corresponding author: gonf@vt.edu gain $(0.62 \mathrm{~kg} / \mathrm{d})$, and body condition score gain $(0.02$ units; all averages of the 2 treatments). The digestibilities of dry matter $(70.2 \%)$, crude protein $(71.4 \%)$, NDF (36.4\%), and starch (99.8\%) were not affected by treatments. In conclusion, the supplementation of the live yeast did not affect production performance and nutrient digestibility of high-producing dairy cows. A potential interaction between live-yeast supplementation and NDF passage rate, which may have hindered the beneficial effects of live-yeast supplementation on production performance and nutrient utilization, deserves further research.

Key words: yeast, low-forage diet, drought

\section{INTRODUCTION}

The effects of a major drought on dairy farming systems are numerous and include increased concentrate prices, shortages of forage stocks, and increased forage prices, among others. From a nutritional perspective, finding nutritional strategies that sustain production and revenues, while maintaining cows' health, is paramount when facing a drought scenario. Reducing dietary forage to concentrate ratios can be a strategy for "stretching" forage inventories under drought scenarios (Yang et al., 2019). Also, replacing corn grain with other less expensive cereal grains can be another strategy when corn prices increase as a consequence of drought (Yang et al., 2017). However, feeding high-concentrate diets or diets containing grains with rapidly fermentable starch increases the risk of SARA (Humer et al., 2018) and may decrease milk fat concentration (Yang et al., 2018).

Supplementing yeast-derived products has been used as a feeding strategy to increase ruminal $\mathrm{pH}$ and $\mathrm{NDF}$ fermentation (Jiang et al., 2017; Bach et al., 2018a; Dias et al., 2018; Humer et al., 2018). These beneficial effects in the ruminal environment may lead to increased milk yields (Jiang et al., 2017; Bach et al., 2018a; Dias et al., 2018). For instance, Bach et al. (2018a) reported that cows in early lactation (i.e., first 21 DIM) supplemented with a live-yeast product produced $38.7 \mathrm{~kg} / \mathrm{d}$ 
of milk, whereas nonsupplemented cows produced 32.7 $\mathrm{kg} / \mathrm{d}$. The authors attributed this response to the different DMI for supplemented and nonsupplemented cows (18.2 vs. $15.7 \mathrm{~kg} / \mathrm{d}$, respectively). Even though a low-forage diet $(\sim 40 \%$ forage $)$ was fed, the dietary NDF concentration was relatively high (i.e., $34.8 \%$ $\mathrm{NDF}$ ), likely due to the inclusion of fibrous forage sources (e.g., fescue hay and barley straw) in place of corn silage. Jiang et al. (2017) also fed low-forage diets to lactating cows in late lactation (i.e., 284 DIM) and reported greater milk yields for cows supplemented with a yeast-derived product than for nonsupplemented cows (31.7 and $29.6 \mathrm{~kg} / \mathrm{d}$, respectively). In this case, even though corn silage was the sole source of forage, the dietary NDF concentration was relatively high (i.e., $35.9 \% \mathrm{NDF}$ ), likely due to the incorporation of nonforage fibrous sources (Jiang et al., 2017). Dias et al. (2018) also fed low-forage diets $(\sim 41 \%$ forage $)$ to lactating cows in early lactation (i.e., 42 DIM), but with lower concentrations of dietary NDF (i.e., $\sim 33 \%$ NDF), and reported that cows supplemented with a yeast-derived product tended to produce more milk than for nonsupplemented cows (40.2 and $38.7 \mathrm{~kg} / \mathrm{d}$, respectively).

The objective of this study was to evaluate the use of a live-yeast product as a means to attenuate plausible nutritional disturbances caused by feeding low-forage diets containing rapidly fermentable carbohydrates to high-producing cows. We hypothesized that adding a live-yeast product to diets containing low inclusions of forage and rapidly fermentable carbohydrates (i.e., wheat) would improve production performance and nutrient digestibility.

\section{MATERIALS AND METHODS}

\section{Animals, Housing, and Diets}

All procedures involving animals were approved by the Institutional Animal Care and Use Committee of Virginia Tech. Eight primiparous $(569 \pm 35 \mathrm{~kg}$ of BW and $80 \pm 29$ DIM at the beginning of the experiment) and 16 multiparous $(665 \pm 67 \mathrm{~kg}$ of $\mathrm{BW}$ and $64 \pm$ 10 DIM at the beginning of the experiment) Holstein cows were blocked by parity and DIM and randomly assigned to 1 of 2 diets (Table 1 ) for a 12-wk-long period according to randomized complete block design. Cows were housed in a 24-stall pen within a freestall barn and fed once daily (1100 h) by means of a Calan gate system (American Calan Inc., Northwood, NH). Cows were trained for $2 \mathrm{wk}$ before the beginning of the experiment to locate their assigned doors. Fresh water was available ad libitum in the freestall barn.
Diets were formulated to meet the requirements (NRC, 2001) for a 630-kg lactating dairy cow consuming $24 \mathrm{~kg} / \mathrm{d}$ of DM and producing $42 \mathrm{~kg} / \mathrm{d}$ of milk. The formulated diets contained $36.7 \%$ corn silage, $8.3 \%$ alfalfa hay, and $55 \%$ concentrate. A pelleted concentrate lacking the live-yeast product was prepared at a commercial feed mill (Big Spring Mill Inc., Elliston, VA). The live-yeast product (BeneSacc, Global Nutritech Biotechnology LLC, Richmond, VA), which contained $4.5 \times 10^{9} \mathrm{cfu} / \mathrm{g}$ of Saccharomyces cerevisiae, was delivered through a premix that was prepared on-farm by mixing $7.5 \mathrm{~kg}$ of live-yeast product with $625 \mathrm{~kg}$ of soybean meal. Following the provider's recommendations, this dilution rate was selected to provide $0.5 \mathrm{~g}$ of liveyeast product per $1 \mathrm{~kg}$ of DMI, which would provide approximately $5.4 \times 10^{11} \mathrm{cfu} / \mathrm{d}$ assuming a $24-\mathrm{kg} / \mathrm{d}$ DMI (Meller et al., 2014; Bach et al., 2018a). For this process, $7.5 \mathrm{~kg}$ of yeast-product was split and placed in

Table 1. Ingredient and chemical composition of diets (\%, DM basis)

\begin{tabular}{|c|c|c|}
\hline Item & Control & Yeast \\
\hline \multicolumn{3}{|l|}{ Ingredient } \\
\hline Corn silage ${ }^{1}$ & 36.7 & 36.7 \\
\hline Alfalfa hay ${ }^{2}$ & 8.3 & 8.3 \\
\hline Corn grain & 10.4 & 10.4 \\
\hline Wheat grain & 8.7 & 8.7 \\
\hline Soybean meal & 10.8 & 10.8 \\
\hline Soybean hulls & 8.3 & 8.3 \\
\hline Wheat middlings & 4.2 & 4.2 \\
\hline Dry distillers grains with solubles & 8.3 & 8.3 \\
\hline Calcium salts of fatty acids ${ }^{3}$ & 1.5 & 1.5 \\
\hline Live-yeast product ${ }^{4}$ & - & 0.05 \\
\hline Bentonite & 0.63 & 0.63 \\
\hline Sodium bicarbonate & 1.04 & 1.04 \\
\hline Salt & 0.54 & 0.54 \\
\hline Magnesium oxide & 0.17 & 0.17 \\
\hline Trace mineral premix ${ }^{5}$ & 0.42 & 0.42 \\
\hline Vitamin A, D, E & 0.042 & 0.042 \\
\hline Vitamin $\mathrm{E}^{\gamma}$ & 0.003 & 0.003 \\
\hline \multicolumn{3}{|l|}{ Nutrient } \\
\hline Ash & 6.2 & 6.3 \\
\hline $\mathrm{CP}$ & 14.7 & 14.8 \\
\hline NDF & 26.7 & 26.9 \\
\hline Forage NDF & 14.2 & 14.3 \\
\hline Starch & 27.9 & 28.1 \\
\hline
\end{tabular}

${ }^{1}$ Corn silage: $34.1 \%$ DM, $6.5 \%$ CP, $31.4 \% \mathrm{NDF}, 19.9 \%$ ADF, $1.7 \%$ ADL, $37.5 \%$ starch.

${ }^{2}$ Alfalfa hay: $88.3 \%$ DM, $23.4 \% \mathrm{CP}, 32.2 \% \mathrm{NDF}, 28.3 \% \mathrm{ADF}, 5.4 \%$ ADL, $1.0 \%$ starch.

${ }^{3}$ EnerGII (Virtus Nutrition LLC, Corcoran, CA).

${ }^{4}$ BeneSacc (Global Nutritech Biotechnology LLC, Richmond, VA).

${ }^{5}$ Contained $22.25 \%$ calcium, $7.50 \%$ magnesium, $2.75 \%$ potassium, $3.90 \%$ sulfur, $1.50 \%$ manganese, $1.50 \%$ zinc, $9,500 \mathrm{mg} / \mathrm{kg}$ of iron, 2,500 $\mathrm{mg} / \mathrm{kg}$ of copper, $200 \mathrm{mg} / \mathrm{kg}$ of iodine, $200 \mathrm{mg} / \mathrm{kg}$ of cobalt, $66 \mathrm{mg} / \mathrm{kg}$ of selenium, $227,273 \mathrm{IU} / \mathrm{kg}$ of vitamin $\mathrm{A}, 136,364 \mathrm{IU} / \mathrm{kg}$ of vitamin $\mathrm{D}_{3}$, and $636 \mathrm{IU} / \mathrm{kg}$ of vitamin E.

${ }^{6}$ Contained $3,500 \mathrm{IU} / \mathrm{kg}$ of vitamin $\mathrm{A}, 950 \mathrm{IU} / \mathrm{kg}$ of vitamin $\mathrm{D}_{3}$, and $2,000 \mathrm{IU} / \mathrm{g}$ of vitamin $\mathrm{E}$.

${ }^{7}$ Contained $500 \mathrm{IU} / \mathrm{g}$ of premix. 
$420-\mathrm{L}$ plastic buckets containing about $3 \mathrm{~kg}$ of soybean meal each. After mixing carefully with a feed scoop, $1 / 4$ of the mix from each of the 4 buckets was placed in a fifth bucket (this last step was repeated 3 more times). Then, the composite mixtures were slowly scooped, while mixing, into a vertical mixer (NDEco FS600, Sioux Falls, SD) containing $625 \mathrm{~kg}$ of soybean meal. After the composite mixtures were completely added, the final premix was mixed for 20 min. Finally, after the mixing was complete, the premix was placed into 40-lb yellow-colored bags that were sewn with an electric sewing machine (Happybuy Bag Closing Machine, Amazon.com Inc., Seattle, WA). To ensure the viability of the yeast, 2 batches of yeast-containing premix were prepared throughout the experiment. For the control treatment, soybean meal was directly placed into 40-lb orange-colored bags that were also sewn as described previously. Soybean meal that was not included in the pelleted concentrate was supplied at a rate of $1 \mathrm{~kg}$ for every $24 \mathrm{~kg}$ of DM.

Mixing and feeding was performed using a Calan Data Ranger mixer (American Calan Inc.). At feeding time, the TMR was prepared by sequentially adding the forage mix, the pelleted concentrate, and the treated or nontreated soybean meals into the mixer. The treated and nontreated soybean meals were spread slowly while mixing into the Calan Data Ranger mixer. The TMR was delivered in quantities enough to allow 5 to $10 \%$ refusals. The amount of feed offered and refused was measured daily. Cows were milked twice daily (0100 and $1300 \mathrm{~h}$ ), and milk weights were automatically recorded at each milking. The weekly averages of daily milk yields and DMI were used for statistical analysis.

\section{$B W$ and $B C S$}

All cows were weighed, and weights were recorded automatically, after each milking session. Data from 6 consecutive milking sessions obtained from d 1 to 3 were used to obtain the initial BW, and data from 6 consecutive milking sessions obtained from d 82 to 84 were used to obtain the final BW. Body condition from all cows was scored ( 1 to 5 scale with 0.25 intervals) by 2 members of the research team (GF and ESR) and the herd manager on $\mathrm{d} 1$ and 84 .

\section{Nutrient Digestibility}

Total-tract nutrient digestibility was estimated using 240-h undigested NDF (uNDF) as an internal marker. For this, 12 fecal grab samples were collected at 10-h intervals throughout a 5 -d sampling period. After drying at $55^{\circ} \mathrm{C}$ in a forced-air oven (Memmert UL 83, Wisconsin Oven Corporation, East Troy, WI) for at least $7 \mathrm{~d}$, the fecal samples were composited and ground to pass through a 1-mm screen of a Wiley mill (Thomas Scientific, Swedesboro, NJ). To determine the concentration of uNDF in TMR and fecal samples, 0.25 $\mathrm{g}$ of ground sample was placed into F57 filter bags (Ankom Technology, Macedon, NY) that were previously soaked in acetone. For each TMR and fecal sample, 6 bags were prepared and sealed, and 2 of each of these 6 bags were incubated for $10 \mathrm{~d}$ into the rumen of 1 of 3 rumen-cannulated cows. The in situ incubations were performed after the actual experiment was completed. Therefore, the rumen-cannulated lactating cows were consuming a diet (i.e., $37.6 \%$ corn silage, $5.4 \%$ pearl millet silage, $3.8 \%$ alfalfa hay, and $53.2 \%$ concentrate) different than the experimental diets. After the incubation period had concluded, bags were rinsed with water until clear water was evident. The concentration of UNDF was determined by subjecting the residues to NDF analysis as described below (see sample collection and analysis). Once uNDF concentrations were determined in both TMR and fecal samples, DM, and nutrient digestibilities were determined using equations [1] and [2], respectively.

$$
\begin{aligned}
& \text { DM digestibility }(\%)= \\
& 100-\frac{\text { dietary uNDF }(\mathrm{mg} / \mathrm{g} \text { of } \mathrm{DM})}{\text { fecal uNDF }(\mathrm{mg} / \mathrm{g} \text { of } \mathrm{DM})} \times 100, \\
& \text { nutrient digestibility }(\%)= \\
& 100-\frac{\text { dietary uNDF }(\mathrm{mg} / \mathrm{g} \text { of } \mathrm{DM})}{\text { fecal } \mathrm{uNDF}(\mathrm{mg} / \mathrm{g} \text { of } \mathrm{DM})} \\
& \times \frac{\text { fecal nutrient }(\mathrm{g} / \mathrm{g} \text { of } \mathrm{DM})}{\text { dietary nutrient }(\mathrm{g} / \mathrm{g} \text { of } \mathrm{DM})} \times 100
\end{aligned}
$$

\section{Sample Collection and Analysis}

Samples of feed ingredients, TMR, and feed refusals were collected weekly. All samples were dried to a constant weight at $55^{\circ} \mathrm{C}$ in a forced-air oven (Freas 645, Thermo Electron Corporation, Marietta, $\mathrm{OH}$ ) and ground to pass through a 1-mm screen of a Wiley mill (Thomas Scientific). Ash concentration was determined after combusting samples in a furnace (Thermolyne 30400, Barnstead International, Dubuque, IA) for $3 \mathrm{~h}$ at $600^{\circ} \mathrm{C}$ (Method 942.05, AOAC International, 2016). Crude protein concentration was calculated as percent $\mathrm{N} \times 6.25$ after combustion analysis (Method 990.03, AOAC International, 2016) using a Vario El Cube CN analyzer (Elementar Americas, Inc., Mount Laurel, NJ). Ash-free NDF and ADF concentrations were determined using the Ankom ${ }^{200}$ Fiber Analyzer 
(Ankom Technology, Macedon, NY). Sodium sulfite and $\alpha$-amylase (Ankom Technology) were included for NDF analysis (Ferreira and Mertens, 2007). Acid detergent fiber and lignin concentrations were determined sequentially. After determining ADF weights, residues were incubated for $3 \mathrm{~h}$ in $72 \%$ sulfuric acid within a 4 -L jar that was placed in a Daisy ${ }^{\mathrm{II}}$ Incubator (Ankom Technology). Starch concentration was determined using the acetate buffer method of Hall (2009) with $\alpha$-amylase from Bacillus licheniformis (FAA, Ankom Technology) and amyloglucosidase from Aspergillus niger (E-AMGDF, Megazyme International, Wicklow, Ireland). Milk samples (a.m. and p.m. milkings) were collected weekly for the determination of milk fat, true protein, lactose, and MUN concentrations with a CombiFoss FT+ fourier transform infrared analyzer (Foss, Hillerød, Denmark) by United DHIA (Radford, VA).

Yeast colony counts were determined in soybean meal samples following a procedure provided by the yeast supplier (Global Nutritech Biotechnology LLC). Briefly, $10 \mathrm{~g}$ of feed was blended (Waring, Torrington, $\mathrm{CT}$ ) for $30 \mathrm{~s}$ with $90 \mathrm{~mL}$ of a sterile peptone solution previously autoclaved at $121^{\circ} \mathrm{C}$ for $20 \mathrm{~min}$. The peptone solution was prepared by dissolving $1.0 \mathrm{~g}$ of Bacto Peptone (C994L09, Thomas Scientific), $8.5 \mathrm{~g}$ of $\mathrm{NaCl}$, and $1.0 \mathrm{~g}$ of Tween 80 (C993J44, Thomas Scientific) into 1 $\mathrm{L}$ of ultra-pure water. After blending, $1 \mathrm{~mL}$ of sample plus peptone blend was diluted in $9 \mathrm{~mL}$ of sterile peptone solution and, from there, serial-diluted (6 dilutions total). For each of the 6 dilutions, $100 \mathrm{~mL}$ of the diluted solution was spread onto dichloran rose bengal chloramphenicol (DRBC, 1221U65, Thomas Scientific) agar plates. After inoculation, all plates were incubated (Boekel Scientific, Feasterville, PA) at $25^{\circ} \mathrm{C}$ for $3 \mathrm{~d}$. Colonies were counted only for plates showing more than 20 and less than 200 pink colonies per plate. Each dilution was plated in triplicate.

\section{Statistical Analysis}

All variables were analyzed using the MIXED procedure of SAS (SAS version 9.4, SAS Institute Inc., Cary, NC). Dry matter intake, milk yield, and milk component concentrations and yields were analyzed using repeated measures. The statistical model for the variables included the effects of block (random; $\mathrm{df}=$ 11), treatment (fixed; $\mathrm{df}=1$ ), the block by treatment interaction (random; $\mathrm{df}=11$ ), week (fixed; $\mathrm{df}=11$ ), the treatment by week interaction (fixed; $\mathrm{df}=11$ ), and the random residual error. Based on Akaike's criterion (Littell et al., 1996), we selected the autoregressive order 1 covariance structure to test the effects of week. The statistical model for analyzing BW gain, BCS gain, DM digestibility, and nutrient digestibility included the effects of block (random; $\mathrm{df}=11$ ), treatment (fixed; $\mathrm{df}$ $=1$ ), and the random residual error. Significant differences between main effects were declared at $P<0.05$.

\section{RESULTS AND DISCUSSION}

Supplementing live yeast to lactating dairy cows did not affect DMI $(P=0.99)$, milk yield $(P=0.97)$, milk fat concentration $(P=0.99)$, milk fat yield $(P=0.92)$, milk protein concentration $(P=0.84)$, milk protein yield $(P=0.84)$, milk lactose concentration $(P=0.90)$, milk lactose yield $(P=0.98)$, and $\mathrm{MUN}(P=0.99$; Table 2). The interaction between diet and time was significant for DMI $(P<0.01)$. The supplementation of live yeast to lactating dairy cows did not affect BW $(P=0.38)$ and BCS gains $(P=0.27$; Table 2$)$, or the digestibilities of DM $(P=0.80), \mathrm{CP}(P=0.52), \mathrm{NDF}$ $(P=00.97)$, and starch $(P=0.37$; Table 3$)$.

Contrary to our hypothesis, supplementing a liveyeast product did not affect production performance and nutrient utilization, and multiple reasons can

Table 2. Production performance of high-producing dairy cows consuming a low-forage diet with or without a live-yeast additive

\begin{tabular}{|c|c|c|c|c|c|c|}
\hline Variable & \multicolumn{2}{|c|}{ Diet } & SEM & \multicolumn{3}{|c|}{$P$-value } \\
\hline Milk yield, $\mathrm{kg} /$ cow per $\mathrm{d}$ & 48.0 & 48.1 & 2.43 & 0.97 & 0.01 & 0.87 \\
\hline Milk fat, $\%$ & 3.60 & 3.61 & 0.22 & 0.99 & 0.01 & 0.32 \\
\hline Fat yield, $\mathrm{kg} /$ cow per $\mathrm{d}$ & 1.71 & 1.73 & 0.10 & 0.92 & 0.01 & 0.32 \\
\hline Milk protein, \% & 2.97 & 2.95 & 0.06 & 0.84 & 0.01 & 0.11 \\
\hline Lactose yield, $\mathrm{kg} /$ cow per d & 2.34 & 2.35 & 0.12 & 0.98 & 0.01 & 0.99 \\
\hline $\mathrm{MUN}, \mathrm{mg} / \mathrm{dL}$ & 7.98 & 7.99 & 0.52 & 0.99 & 0.01 & 0.03 \\
\hline BW gain, $\mathrm{kg} /$ cow per $\mathrm{d}$ & 0.53 & 0.71 & 0.13 & 0.38 & $\mathrm{NA}^{1}$ & NA \\
\hline BCS gain, units/cow per d & -0.04 & 0.08 & 0.08 & 0.27 & NA & NA \\
\hline
\end{tabular}

\footnotetext{
${ }^{1} \mathrm{NA}=$ not applicable.
} 
Table 3. Apparent DM and nutrient digestibility of high-producing dairy cows consuming a low-forage diet with or without a live-yeast additive

\begin{tabular}{lcccc}
\hline Variable & Control & Yeast & SEM & $P$-value \\
\hline DM, \% & 70.2 & 70.1 & 0.47 & 0.80 \\
CP, \% & 71.0 & 71.7 & 0.77 & 0.52 \\
NDF, \% & 36.3 & 36.4 & 1.18 & 0.97 \\
Starch, \% & 99.8 & 99.8 & 0.04 & 0.37 \\
\hline
\end{tabular}

explain this lack of response. On a weekly basis, we collected samples of soybean meal with and without the live-yeast product. After culturing these samples, we confirmed that the yeast was alive throughout the experiment $\left(5.17 \times 10^{7} \mathrm{cfu} / \mathrm{g}\right.$ of soybean meal $)$; therefore, we discarded the possibility of an inactive product. We also confirmed the absence of yeast growth in the control soybean meal.

Supplementation of yeast-derived products has affected the ruminal environment and, therefore, has been used as a feeding strategy to prevent rumen upsets (Bach et al., 2018a; Humer et al., 2018). For this experiment, we formulated diets to challenge the ruminal conditions through a relatively low NDF concentration and using wheat grain, a starch source of rapid fermentability, as one of the energy sources. Based on these challenging conditions, we expected some indications of affected performance, such as low milk yields or low concentrations of milk fat. Despite our expectations, milk yields were satisfactory for high-producing cows $(>48 \mathrm{~kg} / \mathrm{d})$, and milk fat concentrations $(>3.60 \%$ fat $)$ did not indicate signs of milk fat depression. Related to this adequate performance, sodium bicarbonate $(\sim 260$ $\mathrm{g} / \mathrm{d})$ and magnesium oxide $(\sim 44 \mathrm{~g} / \mathrm{d})$ were included in these diets as dietary buffers (Yang et al., 2017, 2018, 2019). If the challenging rumen environmental conditions were attenuated by the inclusion of these buffers, then the action of the supplemental yeast may have been hindered. In agreement with this possibility, after challenging high-producing cows by replacing forages with barley grain, Bach et al. (2018b) reported that rumen $\mathrm{pH}$ was greater for cows fed $200 \mathrm{~g} / \mathrm{d}$ of sodium bicarbonate or $100 \mathrm{~g} / \mathrm{d}$ of a magnesium oxide-based product compared with cows not fed any buffer.

Although the previous discussion may imply that ruminal conditions were not as challenging as expected, the low NDF digestibility (36.4\% NDF digestibility) may indicate that conditions for NDF digestion were not optimal. One purpose for supplementing yeastderived products is to enhance NDF digestion (Dias et al., 2018). Therefore, it seems unexpected to have a low NDF digestibility in both treatments. Perhaps the low concentration of forage NDF $(14.3 \% \mathrm{DM})$, the low proportion of forage NDF $(53.8 \% \mathrm{NDF})$, or their combination have resulted in very fast rates of passage (Mertens and Ely, 1979; Weidner and Grant, 1994). For example, data from Weidner and Grant (1994) showed that the rate of passage of soyhulls from the rumen was $16 \%$ faster for cows consuming diets containing greater proportions of nonforage fiber sources than for cows consuming diets with greater proportions of forage sources. Assuming the enhanced fibrolytic action depends on microbial adhesion to fiber particles, the potential benefit of supplementing the live-yeast product may have been hindered by a rapid rate of passage of fiber particles. In agreement with this possibility, the relatively high DMI observed in this study (i.e., $4.1 \%$ of BW) supports the possibility of a fast passage rate of NDF (Mertens and Ely, 1979).

The plausible relationship between the response to yeast supplementation and NDF passage rate can be supported by results from previous studies (de Ondarza et al., 2010; Jiang et al., 2017; Bach et al., 2018a). Bach et al. (2018a), who reported greater milk yields for cows supplemented with a live-yeast product than for nonsupplemented cows, fed low-forage diets but with relatively high concentrations of NDF $(34.8 \% \mathrm{NDF})$ or forage NDF. Also, the inclusion of fibrous forage sources, such as fescue hay and barley straw, combined with the absence of corn silage, may have helped to slow down the rate of passage of the feed (Mertens and Ely, 1979; Weidner and Grant, 1994), therefore allowing the cows to express the beneficial effect of yeast supplementation. In the case of Jiang et al. (2017), who also reported greater milk yields for cows supplemented with a live-yeast product than for nonsupplemented cows, the dietary NDF concentration was substantially higher than in the current study (35.9 and 26.8\% NDF, respectively). In their meta-analysis, de Ondarza et al. (2010) reported that fermentable NDF was a major determinant of the response of milk yield by dairy cows to dietary yeast supplementation. Therefore, acknowledging this is speculative, the response of production performance to yeast supplementation might be dependent on the rate of passage of the feed (particularly NDF) through the rumen.

The current study is not the only one showing no effects of yeast supplementation on production performance (Kung et al., 1997; Ambriz-Vilchis et al., 2017). Kung et al. (1997) performed one study with cows in early lactation and another study with cows in mid lactation (75 and 120 DIM, respectively) and reported no effects on milk production when cows were supplemented with a live-yeast product. Ambriz-Vilchis et al. (2017) performed 3 studies in commercial dairy farms and also reported no effects on milk production when cows were supplemented with a live-yeast product. As stated by Ambriz-Vilchis et al. (2017), the response 
of milk production to yeast supplementation has been variable, and the proposed benefits of supplementing yeast-derived products have not been consistently demonstrated.

The scope this study was to attenuate plausible nutritional disturbances when feeding relatively lowforage diets containing rapidly fermentable carbohydrates to high-producing cows in early to mid lactation. Maintaining cows' health is paramount when reducing dietary forage to concentrate ratios as a strategy for "stretching" forage inventories under drought scenarios (Yang et al., 2019). In this long-term study, production performance was adequate, despite the aforementioned feeding strategies, suggesting that there is some flexibility or adaptation of cows to challenging feeding conditions. Even though this flexibility may provide confidence to nutritionists, the aforementioned feeding strategies may have higher risks of disturbances in other conditions, such as under environmental heat stress or when feeding mycotoxin-containing feeds.

\section{CONCLUSIONS}

Under the conditions of this experiment, the supplementation of a live yeast did not affect production performance and nutrient digestibility by high-producing dairy cows. Even though we aimed to challenge the rumen environment by feeding relatively low-forage diets containing rapidly fermentable carbohydrates to high-producing cows, the conditions may have not been challenging enough to show the beneficial effects of yeast supplementation on production performance or nutrient utilization. A potential interaction between yeast supplementation and NDF passage rate, which may have hindered the beneficial the effects of yeast supplementation on production performance and nutrient utilization, deserves further research.

\section{ACKNOWLEDGMENTS}

We are grateful to Virginia Tech's undergraduate students Claudia Bollinger, Sarah Thomas, and Becky Wilkins (Department of Dairy Science) for their assistance feeding the cows and collecting, processing, and analyzing the samples. This project was funded by Global Nutritech Biotechnology LLC (Richmond, VA).

\section{REFERENCES}

Ambriz-Vilchis, V., N. S. Jessop, R. H. Fawcett, M. Webster, D. J. Shaw, N. Walker, and A. I. Macrae. 2017. Effect of yeast supplementation on performance, rumination time, and rumen $\mathrm{pH}$ of dairy cows in commercial farm environments. J. Dairy Sci. 100:5449-5461.

AOAC International. 2016. Official Methods of Analysis of AOAC International. 20th ed. AOAC International, Rockville, MD.

Bach, A., I. Guasch, G. Elcoso, F. Chaucheyras-Durand, M. Castex, F. Fàbregas, E. Garcia-Fruitos, and A. Aris. 2018a. Changes in gene expression in the rumen and colon epithelia during the dry period through lactation of dairy cows and effects of live yeast supplementation. J. Dairy Sci. 101:2631-2640.

Bach, A., I. Guasch, G. Elcoso, J. Duclos, and H. Khelil-Arfa. 2018b. Modulation of rumen $\mathrm{pH}$ by sodium bicarbonate and a blend of different sources of magnesium oxide in lactating dairy cows submitted to a concentrate challenge. J. Dairy Sci. 101:9777-9788.

de Ondarza, M. B., C. J. Sniffen, L. Dussert, E. Chevaux, J. Sullivan, and N. Walker. 2010. Case study: Multiple-study analysis of the effect of live yeast on milk yield, milk component content and yield, and feed efficiency. Prof. Anim. Sci. 26:661-666.

Dias, A. L. G., J. A. Freitas, B. Micai, R. A. Azevedo, L. F. Greco, and J. E. P. Santos. 2018. Effects of supplementing yeast culture to diets differing in starch content on performance and feeding behavior of dairy cows. J. Dairy Sci. 101:186-200.

Ferreira, G., and D. R. Mertens. 2007. Measuring detergent fibre and insoluble protein in corn silage using crucibles or filter bags. Anim. Feed Sci. Technol. 133:335-340.

Hall, M. B. 2009. Determination of starch, including maltooligosaccharides, in animal feeds: Comparison of methods and a method recommended for AOAC collaborative study. J. AOAC Int. 92:42-49.

Humer, E., I. Kröger, V. Neubauer, K. Schedle, N. Reisinger, and Q. Zebeli. 2018. Supplementing phytogenic compounds or autolyzed yeast modulates ruminal biogenic amines and plasma metabolome in dry cows experiencing subacute ruminal acidosis. J. Dairy Sci. 101:9559-9574.

Jiang, Y., I. M. Ogunade, K. G. Arriola, M. Qi, D. Vyas, C. R. Staples, and A. T. Adesogan. 2017. Effects of the dose and viability of Saccharomyces cerevisiae. 2. Ruminal fermentation, performance of lactating dairy cows, and correlations between ruminal bacteria abundance and performance measures. J. Dairy Sci. 100:81028118.

Kung, L., E. M. Kreck, R. S. Tung, A. O. Hession, A. C. Sheperd, M. A. Cohen, H. E. Swain, and J. A. Z. Leedle. 1997. Effects of a live yeast culture and enzymes on in vitro ruminal fermentation and milk production of dairy cows. J. Dairy Sci. 80:2045-2051.

Littell, R. C., G. A. Milliken, W. W. Stroup, and R. D. Wolfinger. 1996. SAS ${ }^{\circledR}$ System for Mixed Models. SAS Institute Inc., Cary, NC.

Meller, R. A., J. L. Firkins, and A. M. Gehman. 2014. Efficacy of live yeast in lactating dairy cattle. Prof. Anim. Sci. 30:413-417.

Mertens, D. R., and L. O. Ely. 1979. A dynamic model of fiber digestion and passage in the ruminant for evaluating forage quality. J. Anim. Sci. 49:1085-1095.

NRC. 2001. Nutrient Requirements of Dairy Cattle. 7th rev. ed. National Academies Press, Washington, DC.

Weidner, S. J., and R. J. Grant. 1994. Altered ruminal mat consistency by high percentages of soybean hulls fed to lactating dairy cows. J. Dairy Sci. 77:522-532.

Yang, Y., G. Ferreira, B. A. Corl, and B. C. Campbell. 2019. Production performance, nutrient digestibility, and milk fatty acid profile of lactating dairy cows fed corn silage- or sorghum silage-based diets with and without xylanase supplementation. J. Dairy Sci. 102:2266-2274.

Yang, Y., G. Ferreira, C. L. Teets, B. A. Corl, W. E. Thomason, and C. A. Griffey. 2017. Effects of feeding hull-less barley on production performance, milk fatty acid composition, and nutrient digestibility of lactating dairy cows. J. Dairy Sci. 100:3576-3583.

Yang, Y., G. Ferreira, C. L. Teets, B. A. Corl, W. E. Thomason, and C. A. Griffey. 2018. Effects of feeding hulled and hull-less barley with low- and high-forage diets on lactation performance, nutrient digestibility, and milk fatty acid composition of lactating dairy cows. J. Dairy Sci. 101:3036-3043. 